\title{
Anatomy of the Seedling of Bowenia spectabilis, Hook. f.
}

\author{
BY
}

H. H. W. PEARSON, B.A.

'Frank Smart' Student at Gonville and Caius College, Cambridge, and Assistant Curator of the University Herbarium.

With Plates XXVII and XXVIII.

THE genus Bowenia was first described in the Botanical Magazine in 1863 , from plants sent to Kew from Rockingham Bay, in that year ${ }^{1}$. The particular interest of the plant from a phylogenetic point of view is centred in its bipinnate leaf, a character which is not found in other Cycads. "With the exception of Stangeria paradoxa, no more remarkable Cycadaceous plant has been discovered than the subject of our present plate, and like that plant it differs from every other member of its Order in the nature of its leaves, which present remarkable analogies with those of Ferns; whereas, however, the anomalous character of Stangeria is affected by the venation of the pinnules, which so exactly simulated those of a Lomaria, that two authors had (unknown to one another) referred it to that genus, the resemblance in the case of Bowenia is in some respects

${ }^{1}$ Curtis's Botanical Magazine, (3) Vol. xix, Tab. 5398. London, I863.

[Annals of Botany, Vo1. XII. No. XLVIII. December, 1898.] 
carried further, inasmuch as the leaf is not simply pinnate as in Stangeria and other Cycadeae, but decompound, like a Marattia ${ }^{1}$ ' The similarity between the leaves of Bowenia and the coal-measure fronds of Neuropteris and Alethopteris has been considered by Stur as evidence in favour of the Cycadean affinities of the latter genera ${ }^{2}$.

A point of great physiological interest is the development of numerous curiously-branched apogeotropic roots from the upper part of the main root. The general appearance of one of these roots is represented in Fig. 2, prepared from a photograph of an old root kindly supplied to me by the Curator of the Royal Gardens, Kew. A physiological examination of these roots was not undertaken: but an interesting feature is the presence of Anabaena-filaments in the majority of those examined. The Alga was found in all of a few roots obtained from $\mathrm{Kew}$, and in some of those obtained from our own plants. As will be seen later, the method of occurrence of the Alga is very similar to that described by Reinke ${ }^{3}$ in the subterranean roots of Cycas, Ceratozamia, Dioon, and Encephalartos.

No Alga was found in the subterranean roots of Bowenia; but, as the only material examined was obtained from the young plants, its general absence must not be concluded. It is worthy of notice that whilst in the cases described by Reinke ${ }^{3}$ the Alga was found in portions of the tissue thickly covered by soil, and was thus placed very unfavourably for assimilation of $\mathrm{CO}_{2}$, in Bowenia, on the other hand, it flourishes chiefly, if not entirely, in roots which are freely exposed to the atmosphere.

My thanks are due to Mr. Lynch for the supply of the seedlings used in this investigation, which were grown at the University Botanic Gardens. Figure I represents a seedling of seven months' growth. Except where specially mentioned, no plants older than this were examined. As

1 J. D. Hooker, in Curtis's Botanical Magazine, loc. cit.

2 A. C. Seward, The Wealden Flora, Part ii, p. 5. London, I895.

${ }^{3}$ Reinke, 'Zwei parasitische Algen,' Bot. Zeitg., I879, p. 473. 
far as the supply of material would allow, comparison was made with younger seedlings: in the cases indicated the sections figured were taken from younger plants.

\section{The SeEd. (Fig. I, s.)}

The embryo occupies an axile position in a copious starchy endosperm whose consistency is compact and almost brittle. The testa is horny and thin. In germination the cotyledons remain within the endosperm and function as an absorbent organ. The depletion of the endosperm is a process of long duration; in some of the oldest seedlings examined the endosperm was by no means all exhausted. At their distal ends the two cotyledons are united into a single club-shaped body which projects into the endosperm (Fig. $3, f$. cot.). A transverse section through this region shows a well-marked line of separation between the two portions of the united cotyledons. The proximal portions and the petioles are free.

The cotyledons are bounded by a definite epithelial layer composed of cells which are elongated in a radial direction, and are rather smaller than the ordinary mesophyll-cells. These cells are filled with dense protoplasmic contents and have large nuclei. The mesophyll-tissue of the cotyledon is composed of large parenchymatous cells of a uniform size.

A single leaf-trace in the stem divides to form about four separate bundles which enter the cotyledons. One or more of these may divide again, so that from four to seven distinct bundles, arranged in an arc, are found in each cotyledon. The bundles are orientated normally, the phloem being on the dorsal side of the xylem. The larger quantity of the xylem is centripetal, a considerable number of centrifugal elements being also developed (Fig. 4). The centripetal xylem is usually somewhat extended in a tangential direction, beyond the general contour of the bundle: one or two elements on the flanks of this portion of the bundle are elongated tangentially and show characteristic reticulate markings on their 
walls (Fig. 4, tr.). These outlying elements would seem to be of the same nature as those described by Worsdell in the cotyledon of Cycas revoluta ${ }^{1}$. The phloem has the usual characters, but contains no fibrous elements such as are so abundant in the root-phloem. The protophloem has not undergone any crushing; in other respects the cotyledonary bundle closely resembles that of the lower part of the petiole of the foliage-leaf. In all the preparations examined, the cotyledonary bundles were strictly collateral ${ }^{2}$.

The plumule is very short and undergoes but a small development during the later history of the plant. The radicle gives rise to a strongly-developed tap-root (Fig. I).

\section{THE RoOT.}

The seedling possesses a well-developed root-system comprising a strong tap-root from which arise numerous lateral branches, some of which are apogeotropic.

The anatomical structure of the main root is in no way abnormal. The stele is usually four- or five-arch, and encloses a well-developed pith. Fig. 5 represents a transverse section of the stelar region; the section was taken from a point about $2 \mathrm{~cm}$. from the apex of a root which was $5 \mathrm{~cm}$. in length. It shows five distinct primary xylem-groups, and three well-marked groups of phloem. In older roots the masses of phloem and xylem are equal in number. The stele is bounded by an endodermis, distinctly marked in older roots, but indistinguishable in the section from which Fig. 5 was prepared.

The pericycle consists of four or five layers of cells. The wide cortex is composed of large parenchymatous cells of a uniform size, which, in the older roots, are densely filled with starch. Many of the cells of the cortex, particularly

1 W. C. Worsdell, On 'transfusion-tissue.' Trans. Linn. Soc. Bot., (2) Vol. v, I 897 , p. 307 .

"A cursory examination of a preparation which Mr. IV. C. Worsdell kindly showed me at Kew was insufficient to convince me of the presence of a concentric bundle in the cotyledon. 
those of the outer cortex, and also several of the pericyclecells, are filled with cluster-crystals of calcium oxalate. Stone-cells are rarely met with in the root.

Increase in thickness in the root is largely due to an irregular division of the cells of the ground-tissue. In the upper part of the root this primary thickening is especially obvious, particularly in the pith, and takes place to such an extent that the vascular bundles become considerably displaced.

A phellogen-layer appears in the outer cortex in the young root, before secondary thickening commences. This is quickly followed by a second layer of phellogen which arises in the pericycle immediately beneath the endodermis. All the tissue outside the inner periderm is quickly cast off. This corresponds with Reinke's observation on the formation of two periderm-layers in the root of Cycas circinalis $^{1}$. A similar condition has also been observed by Gregg in the root of Cycas revoluta ${ }^{2}$.

Secondary thickening occurs in a normal manner. Cambium first appears as an arc on the inner side of each group of phloem (Fig. 5). The ring of cambium enclosing the xylemmasses is soon completed, and simultaneously with this the second phellogen-layer commences to be formed in the pericycle.

As in other Cycads, the cambium-layer gives rise, not to homogeneous masses of xylem and phloem, but to radiallyextended plates more or less widely separated from one another by medullary rays.

Secondary tracheids are produced more plentifully on the flanks of the masses of phloem, in the immediate neighbourhood of the primary xylem groups (Fig. 6, xy. ${ }^{2}$ ). A few tracheids are also formed inside the cambium-ring opposite the plates of secondary phloem. The secondary phloem is composed of radial plates, about four cells wide, each of

\footnotetext{
1 Reinke, Morphologische Abhandlungen. Leipzig, 1873, p. I9.

${ }^{2}$ Gregg, Anomalous Thickening in the Root of Cycas Seemanni, Ann. Bot., Vol. i, I887, p. 64 , footnote.
} 
which is made up of sieve-tubes, some parenchymatous tissue, and small groups of long, very thick-walled, fibrous elements (Fig. 7), which, as $\mathrm{Worsdell}^{1}$ has pointed out in the case of the stem of Macrozamia, must have an important function in an organ so largely composed of parenchymatous tissue. A few cells filled with cluster-crystals of calcium oxalate are also found in the secondary phloem.

Opposite each primary xylem-group the cambium produces no secondary phloem, but a wide medullary ray (Fig. 6, $m . r$.$) . The medullary rays, as well as the pith and pericycle,$ afterwards increase rapidly in extent by primary celldivision, and consequently the arrangement of the secondary tissues, which is at first so regular as to be almost diagrammatic, becomes considerably disturbed.

No indications of growth in thickness of an anomalous character were observed.

The lateral subterranean roots arise in a normal manner from the main root, and are similar to it in structure, though the number of primary xylem-groups is commonly fewer than in the main root. Among the lateral roots a diarch or triarch structure is usually found.

\section{The Apogeotropic Roots.}

These roots spring from the upper portion of the main root, the first of them appearing a short distance below the origin of the cotyledons. Later ones are produced at points lower down, but a pparently not in strictly acropetal succession. The term 'apogeotropic' is strictly correct as applied to these roots, for as soon as they emerge from the main root they grow vertically upwards. When full-grown, the apogeotropic root is from 2 to $4 \mathrm{cms}$. in length, and consists of a cylindrical stalk which bears above the surface of the ground a much-branched 'coralloid' head (Fig. I, $a . g$., and Fig. 2).

A remarkable feature of these roots is that their branching is of an exogenous type. At the apex is a merismatic

1 Worsdell, The Anatomy of the Stem of Macrozamia compared with that of other genera of Cycadeae, Annals of Botany, Vol. x, I896, p. 608. 
tissue composed of small cells. The commencement of branching is indicated by a broadening of the apex, which is succeeded by the longitudinal division of the apical meristem into two apparently equal portions. But the dichotomy is only apparent, for one branch soon shows itself to be stronger than the other. None of the branches grow much in length before undergoing further branching of the same character, and to this is due the characteristic 'coralloid' appearance of the head of the root (Fig. 2).

The apogeotropic root arises, like the ordinary lateral root, endogenously opposite a protoxylem-group of the main root. A cylinder of cambium, continuous with the cambium of the main root, appears in the tissue of the young root before it has yet reached the surface, and gives rise to secondary xylem- and phloem-elements which are continuous with the corresponding elements of the main stele (Fig. 8,a.ph. ${ }^{2}$, $\left.a . x y \cdot{ }^{2}\right)$. The primary structure of the stalk is similar to that of the ordinary lateral root. The stele is diarch, or more frequently triarch (Fig. 9). Primary growth in thickness is very much less than in the ordinary root: pith is usually absent, or, if present, very small in amount. A cambium appears on the inner face of each phloem-mass, but neveras far as was observed-forms a complete ring round the primary xylem-groups (Fig. 9, $c b$.). A single phellogen-layer arises in the external cortical tissue, an inner layer not being developed in the pericycle as in the ordinary root. Starch is found in the cells of the ground-tissue: many of the cells are filled with cluster-crystals of calcium oxalate, which are especially abundant in the cells of the pericycle and inner cortex.

The peripheral ('piliferous') layer of the coralloid head is composed of cells which are radially elongated, their outer ends being free from one another (Fig. IO, p.). This layer gives a villous appearance to the surface which is obvious to the naked eye. A phellogen-layer forms in the external cortex, beneath the papillose layer (Fig. Io, $p l$.), continuous with the phellogen-layer in the stalk. Eventually the papillose layer is cast off and the whole root is enveloped 
in a continuous sheath of cork. As in the stalk, no phellogen is formed in the pericycle.

As has been stated above, most of the apogeotropic roots examined, particularly the older ones, contained colonies of Anabaena. The Alga is found in the intercellular spaces between the cells of a 'palisade-layer' which occurs midway between the periphery of the root and the stele (Fig. I I, $i . c$.). The 'blue-green' ring thus formed is visible to the naked eye in a transverse section. The Alga flourishes most abundantly in the tissues of the 'head'; but in the older roots it is present in a similarly well-defined ring for a considerable distance down the stalk, becoming less abundant lower down, and, in all cases yet examined, disappearing entirely above the junction of the stalk with the main root. The 'palisade-layer' is not seen in roots which contain no Anabaena, and it would seem that the characteristic appearance of the layer is due very largely to the lateral crushing, and consequent radial extension of its cells, by the pressure upon them of the developing colonies of Anabaena (Figs. 12 and I3). In roots in which the Alga is beginning to develop it occurs in small patches between the cells; as it becomes more abundant the cells are forced into the shape represented in Fig. 12, and finally the lumina become quite obliterated, so that neighbouring colonies are separated by radial partitions which can be recognized as collapsed cells only by treatment with re-agents. In this respect the method of occurrence of the Algal colonies in the apogeotropic root of Bowenia differs from that described by Reinke for Cycas, in which case a true palisade-layer of very definite form is present ${ }^{1}$. With the exception of a few isolated groups, the Alga is quite confined to this mid-cortical zone, which nowhere approaches nearer the surface of the root, and in many cases forms an uninterrupted layer parallel with the surface of the root.

The Alga is a typical Anabaena, showing characteristic heterocysts.

${ }^{1}$ Reinke, loc. cit., Bot. Ztg., 1879, see Figs. 2 and 3. 


\section{Transition From RoOT to Stem.}

The normal structure of the root is retained to within a few $\mathrm{mm}$. of the insertion of the cotyledons. The first indication of change is seen in the reduction of the pentarch structure to triarch : this is brought about by the disappearance of two protophloem-groups (see Fig. 5) and the subsequent union of the two adjacent pairs of protoxylem-groups to form two distinct masses. The result is, three groups of phloem, and three alternating groups of xylem, two of which represent a fused pair each. The diameter of the vascular cylinder meanwhile diminishes, as the constituent bundles of xylem and phloem pass in slightly towards the centre. The third and smallest group of protoxylem next passes inwards into the centre, and its elements become scattered in the pith between the two larger groups of xylem (Fig. 21); the two groups of phloem which were formerly separated by this third xylemgroup (Fig. 2I, $p h .^{1}, p h .^{1}$ ), pass towards one another, and eventually become united.

The structure of the cylinder at this stage is as follows:It is of an elliptical form (Fig. 2I), two well-defined protoxylem-groups being situated at the ends of the longer axis of the ellipse (Fig. 21, p. xy.), and the third group of protoxylem represented by a number of tracheids which are scattered in the pith between the polar groups of xylem (Fig. 2I, c. xy.). On one flank of the xylem-plate is a single large group of phloem (Fig. $2 \mathrm{I}, p h$.) showing a distinct band of crushed protophloem $(p \cdot p h$.). On the opposite side of the xylem-plate are two smaller groups of phloem $\left(p h .^{1}, p h{ }^{1}\right)$ which were separated by the third group of protoxylem, and which will shortly unite to form a single bundle. Each of the three phloem-groups is bounded on its inner face by cambium, to which is due a considerable development of secondary phloem and a few secondary tracheids (Fig. 2I, xy. ${ }^{2}$ ). As far as could be ascertained, this structure is always to be found in the region of transition, though it is not always 
preceded by a definitely triarch stage as described and figured in this case. When the triarch arrangement does not occur, the xylem-masses pass to the centre, as in the case of the triarch cylinder, and the phloem forms two masses, one on each side of the slightly-elongated band of xylem.

The concentration of the vascular mass in the centre of the hypocotyl proceeds, and the cambium becomes extended, and finally more or less completely surrounds a central mass of xylem. At this stage the centre of the stele is occupied by a mass composed of three groups of protoxylem (Fig. I $4, p . x y$.), no pith being present. The cambium gives rise to secondary xylem and phloem and wide medullary rays (Fig. I 4): but the cambium and the tissues formed from it never completely surround the central mass of protoxylem. The diameter of the whole cylinder is, however, very small compared with that of the hypocotyl. The cylinder has this structure at the point of origin of the cotyledons, and for a very short distance (about $\frac{1}{2} \mathrm{~mm}$.) below it.

\section{The Stem.}

The plumule undergoes very slight development, and the stem is, in consequence, very short. The growing-point becomes displaced laterally by the leaves, and is enclosed in the sheathing base of the youngest of them.

At the insertion of the cotyledons the central vascular mass (Fig. I4) breaks up into two equal portions, from which are derived the cotyledonary leaf-traces. The remainder of each portion divides into several smaller bundles, which in the lower part of the stem are arranged in a more or less regular ring around the enveloped pith. Above this the stem-bundles pursue a very irregular and generally oblique course, meanwhile giving off traces which pass to the foliage-leaves.

The xylem is entirely centrifugal in origin (Fig. I5). As has been shown for other Cycads ${ }^{1}$, the secondary wood is

${ }^{1}$ Worsdell, loc. cit., Ann. Bot., vol. x, I896, \&c. 
divided up into narrow radial bands separated by medullary rays of equal width (Fig. $\left.15, x y_{.}^{2}\right)$. The protophloem forms a wide band of crushed tissue (Fig. I $5, p . p h$.): the secondary phloem contains no fibrous elements such as are so abundant in the phloem of the root.

In the upper portion of the stem the orientation of the bundle is by no means constant, and occasionally bundles are found whose orientation is inverted.

The stem is surrounded by a layer of cork continuous with the pericyclic periderm of the root. The cells of the phelloderm contain numerous cluster-crystals of calcium oxalate. The cells of the ground-tissue have undergone a considerable amount of primary division. Many large mucilage-canals traverse the stem in an obliquely longitudinal direction in the neighbourhood of the vascular bundles, though it is not easy to trace any constant relation between the direction of the canal and that of the bundle. The canals are not continued into the root: branches are given off which pass into the leaves, but they are not found in the cotyledons. A large mucilage-cavity is found near the stem-apex, with which the canals communicate.

\section{The LEAF.}

The leaf consists of a swollen leaf-base, a long petiole, and a bipinnate lamina (Fig. I). The young leaf has well-marked circinate vernation : its younger portion is protected by brown uniseriate hairs, each of which consists of a short basal cell upon which is inserted a long terminal cell.

The leaf-base is crescent-shaped in transverse section (Fig. I6). The edges of the base of the youngest leaf fold round, and enclose the growing-point of the stem. A peripheral band of cork is formed in the ground-tissue (Fig. I6 c.). The vascular bundles are orientated normally, the xylem being on the ventral side. In structure the bundle of the leaf-base is similar to that of the leaf-trace in the stem (Fig. I5), except that a few elements of centripetal wood, which become more 
abundant higher up the petiole (cf. Fig. I 8), have appeared. The general ground-tissue consists of parenchymatous starchcontaining cells, among which are scattered numerous mucilage-canals, particularly in the neighbourhood of the bundles (Fig. I6, m.c.); these are continuous with the canals of the stem, and higher up unite to form the single central canal of the petiole (Fig. I $7, m . c$. .). Numerous cells containing clustercrystals of calcium oxalate are present, especially in the phelloderm. In the upper part of the leaf-base an irregularlyarranged band of stereome appears in the peripheral cortical tissue, and afterwards attains a greater development in the petiole.

No periderm is formed in the petiole. The epidermis and two layers of cells immediately beneath it are composed of very thick-walled cuticularized cells, forming a peripheral band of stereome which is interrupted by stomata (Fig. I7). Beneath it is an irregularly-arranged band of stereome, continuous with the similar band in the leaf-base. The vascular bundles of the leaf-base have undergone some fusion, and the petiole contains, usually, four resulting bundles which are orientated towards the centre, around the single central mucilage-canal (Fig. I7). The vascular bundle contains some centripetal wood (Fig. 18, $c p . x y$.), which increases in quantity towards the upper end of the petiole (Fig. 19, cp.xy.). The protophloem is represented by a wide band of collapsed tissue $(p . p h$.$) . In the secondary petiole the bundle shows a still$ further increase of centripetal wood, and decrease in number of centrifugal elements. This preponderance of centripetal over centrifugal elements increases in the higher parts of the bundle until, in the lamina itself, the xylem is almost entirely centripetal, centrifugal elements being absent or one or two only (Fig. 20). Transfusion-tissue is possibly represented by one or two more or less transversely-elongated elements on the flanks of the centripetal xylem, which however do not show the markings characteristic of that tissue (Fig. 20, $t$.). The inconspicuous character of these elements may of course be attributed to the age of the leaf: no old leaves were 
examined with a view of determining the development of the transfusion-tissue. But it is equally probable that a poor development of this tissue is characteristic of Bowenia, as it has been shown to be in the case of Stangeria ${ }^{1}$. Bowenia and Stangeria are alike in that the venation of the leaf consists of closely-arranged sub-parallel members of a dichotomously-branched system, by means of which the leaf is well supplied with conducting-tissue: and under these circumstances it is reasonable to suppose that the specialization of transfusion-tissue is less necessary than in cases in which the leaf is not so well provided with ordinary conductingtissue.

Engler's statement ${ }^{2}$ that the anastomosis of the veins described by Schimper does not occur, is confirmed in the case of the leaves of the seedling-plant.

The general structure of the lamina of the adult leaf has been fairly fully described by Nestler ${ }^{3}$. With a single, not unimportant, exception, this account is correct for the leaves of the seedling-plant. He states (p. 356) that the stomata of Bowenia differ from those of all other Cycads in that they are found upon the upper as well as the lower side of the leaf. Though many leaves were examined, not a single stoma was found upon the upper side of the leaf; whilst stomata of the kind described by Nestler were very abundant on the lower side. In comparing these two accounts it should be borne in mind that our plants were grown under glass in the Tropical Pit, a condition which may have affected the development of the stomata.

It was perhaps to be anticipated that an examination of young plants of Bowenia would disclose the existence of primarily concentric vascular bundles, the presence of which would lend support to the phylogenetic evidence supplied by the bipinnate leaf. However, no indication of the existence of such bundles in any part of the plant has been found in the

1 Worsdell, loc. cit., Trans. Linn. Soc.

2 Engler and Prantl, ii. I, p. 9.

3 'Ein Beitrag zur Anatomie der C ycadeenfiedern,' Pringsheim's Jahrbuicher, Vol. xxvii, 1895, p. 356 . 
course of this work, though Mr. Worsdell informs me that he has seen a concentric bundle in the cotyledon.

The apogeotropic roots seem to form the most interesting feature of the plant, whether from a morphological or physiological point of view. An account of the mode of life of the plant, and the kind of habitat in which it flourishes in its wild state, might throw some light upon the importance of the functions of these remarkable organs. There can be no doubt that the presence of colonies of Anabaena within the apogeotropic root is a normal circumstance for plants in cultivation, and there is no reason to suppose that the same does not occur in plants in the wild condition. The development of the Alga in the root is from above downwards, and it is not unreasonable to suppose that at some later stage than has been yet examined it extends into the subterranean roots, as Reinke ${ }^{1}$ has described for other Cycads. That the union is of mutual advantage can hardly be doubted, as both the Alga and the tissue surrounding it are in an unmistakably flourishing state. The restriction of the Alga to a definite zone is a very remarkable fact, and the more so since the zone appears to be composed of quite normal cells of the cortex before the appearance of the Alga, by the activity of which its later characteristic form is induced. The entrance of the Alga must be effected by way of the papillose surface of the head of the root, though no indication of this was found. It is noteworthy, that in the older root, where the Alga is found in the most flourishing condition, it is as effectually excluded from the surrounding atmosphere by an uninterrupted layer of cork, as if the organ which encloses it were buried beneath the soil, as was the case in the roots described by Reinke.

In conclusion, I desire to express my thanks to Mr. Seward, at whose suggestion I commenced this investigation, and who has continually assisted me during its progress; to Mrs. Seward, who kindly executed the drawing from which

${ }^{1}$ Reinke, loc. cit., Bot. Zeitg., I87̧9. 
Figure I was prepared; and to Dr. D. H. Scott, to whom I am indebted for valuable advice on several points that have arisen during the course of the work.

The Botanical Laboratory, Cambridge.

\title{
EXPLANATION OF FIGURES IN PLATES XXVII AND XXVIII.
}

\author{
Illustrating Mr. Pearson's paper on Bowenia.
}

The following is a list of the abbreviations used: a. g., apogeotropic root; a. $p h .^{2}$, secondary phloem of apog. root; $a . x y .{ }^{2}$, secondary xylem of apog. root; $c$., cork; $c b$., cambium; $c f . x y$., centrifugal xylem; $c p . x y$., centripetal xylem; $c x$, cortex; $d$. e., depleted endosperm cells; e., endosperm; end, endodermis; $e p$., epithelial layer of cotyledon ; $f$. cot., fused cotyledons ; $f b$., fibres ; $g$., stoma ; i.c., intercellular spaces, containing Anabaena; m.c., mucilage canal ; m.r., primary medullary ray; $m . r^{2}$, secondary medullary ray; $p . p h$., protophloem; $p . x y$., protoxylem; $p$., papillose layer of apogeotropic root; $p h .^{2}$, secondary phloem; pl., phellogen; pc., pericycle; s., seed ; s.c., stone cell ; s.t., sieve-tube; st., petiole of cotyledon; se., stereome; $t$., testa; $v . b$., vascular bundle; $x y .{ }^{2}$, secondary xylem.

Fig. I. Drawing of a young plant, seven months old, $\frac{2}{3}$ natural size.

Fig. 2. From a photograph. An apogeotropic root. $\times 2$.

Fig. 3. Diagram of a median longitudinal section through the seed at the stage shown in Fig. I.

Fig. 4. Transverse section of the vascular bundle in the cotyledon. $\times$ I 80 .

Fig. 5. From a photograph. Transverse section of the stelar region of the main root of a young seedling. $\times 60$.

Fig. 6. Diagram to illustrate mode of secondary thickening in the root.

Fig. 7. Portion of a transverse section of the root, to show the structure of the secondary phloem. $\times$ I 40 .

Fig. 8. Diagram to illustrate mode of origin of the apogentropic root.

Fig. 9. Portion of transverse section of the vascular bundle of the stalk of the apogeotropic root. $\times 180$.

Fig. I0. Portion of transverse section of the 'head' of the apogeotropic root showing the papillose layer. $\times$ 70.

Fig. II. Portion of transverse section of the stalk of the apogeotropic root, to show position of the 'Anabaena-layer.' $\times 68$.

Fig. I2. Ditto. $\times$ I 80 . 


\section{Pearson.-Bowenia spectabilis, Hook. $f$.}

Fig. I3. Portion of longitudinal section of the same. $\times 90$.

Fig. I4. Diagram of a transverse section of the vascular cylinder of the hypocotyl.

Fig. I5. Transverse section of a leaf-trace bundle in the stem. $\times$ r 80.

Fig. I6. Diagram of transverse section through the leaf-base.

Fig. I 7. Diagram of transverse section through the petiole.

Fig. 18. Transverse section of vascular bundle in the lower part of the petiole, $\times$ I80.

Fig. I9. Transverse section of vascular bundle in upper part of petiole. $\times$ I80.

Fig. 20. Transverse section of vascular bundle of the leaf-lamina. $\quad \times 280$.

Fig. 21. Transverse section of vascular cylinder in the hypocotyl. $\quad \times 68$. 


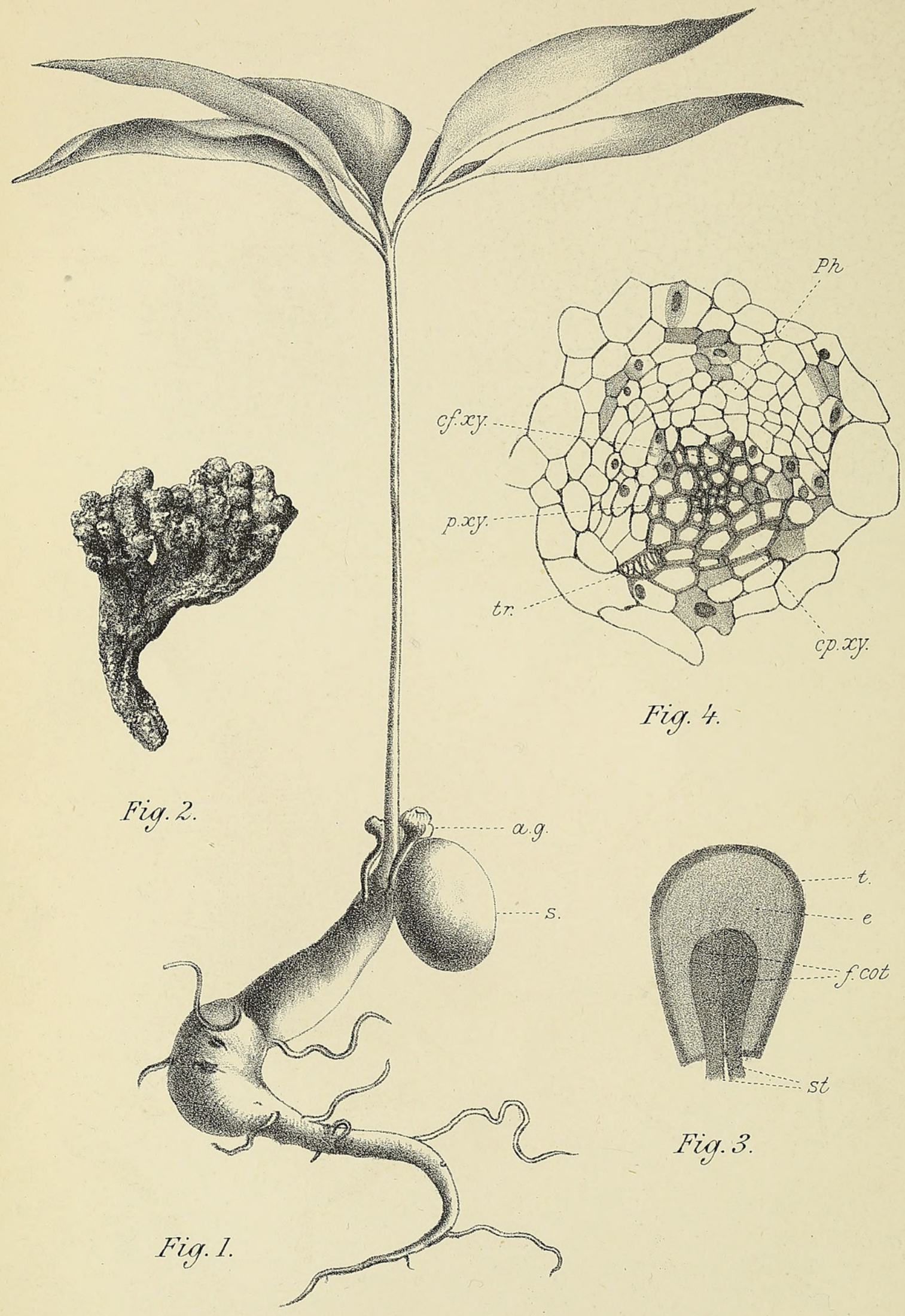

Fiģ.1, M. Seward, Fiġs. 3,4,6-8 H.H.W. Pearson de]

PEARSON. - BOWENIA. 


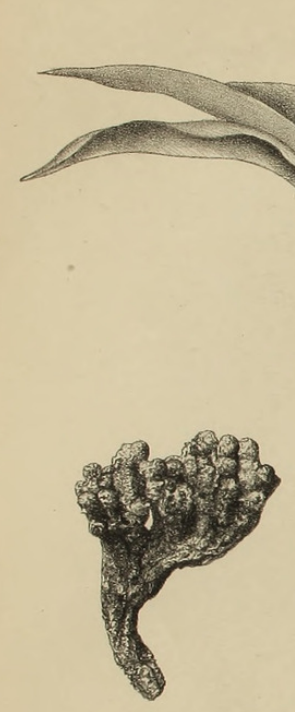

p.pho:

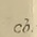

Fig. 2.
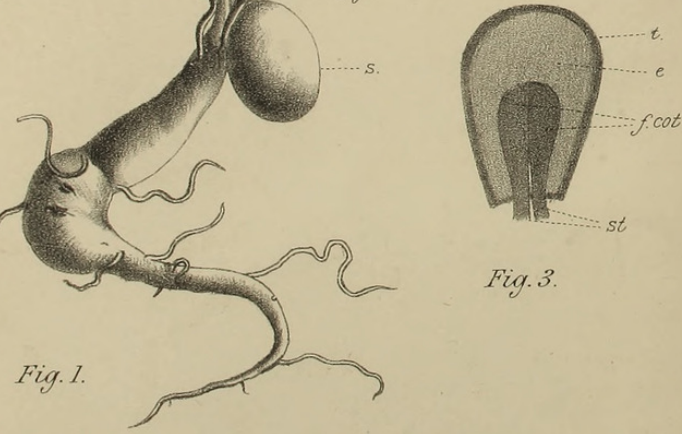

Fig. 3.
Fig. 6.

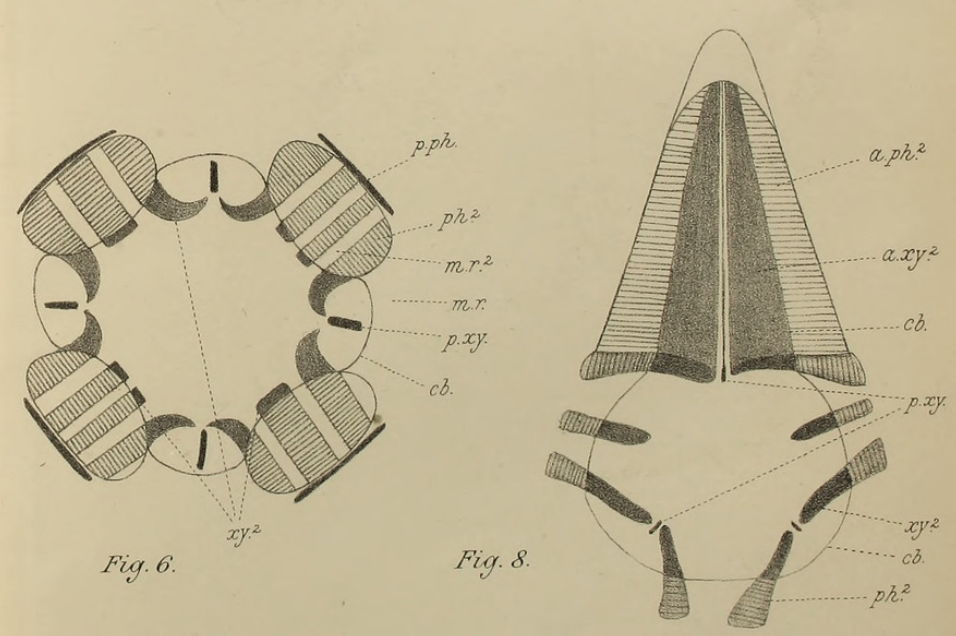

Than

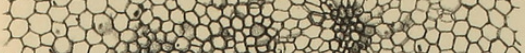

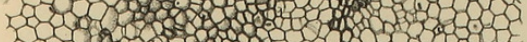

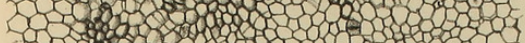

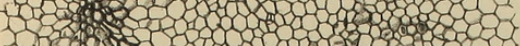

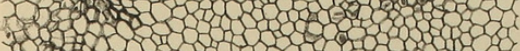

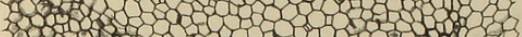

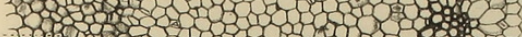

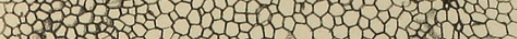
3 030303

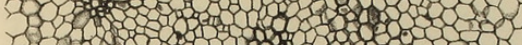

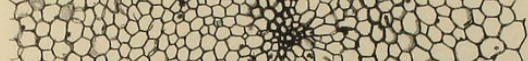

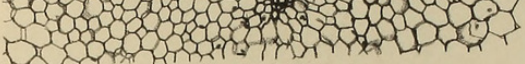

Fig. 5.

University Press, Oxfor 
Fig. 9.

Fig. 10.

जी

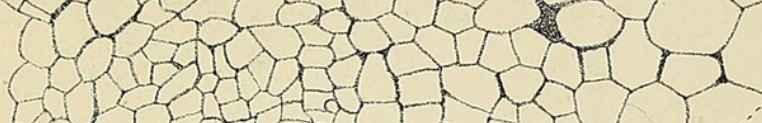

10000000 on

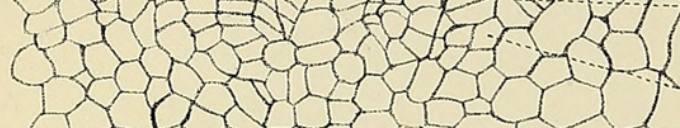
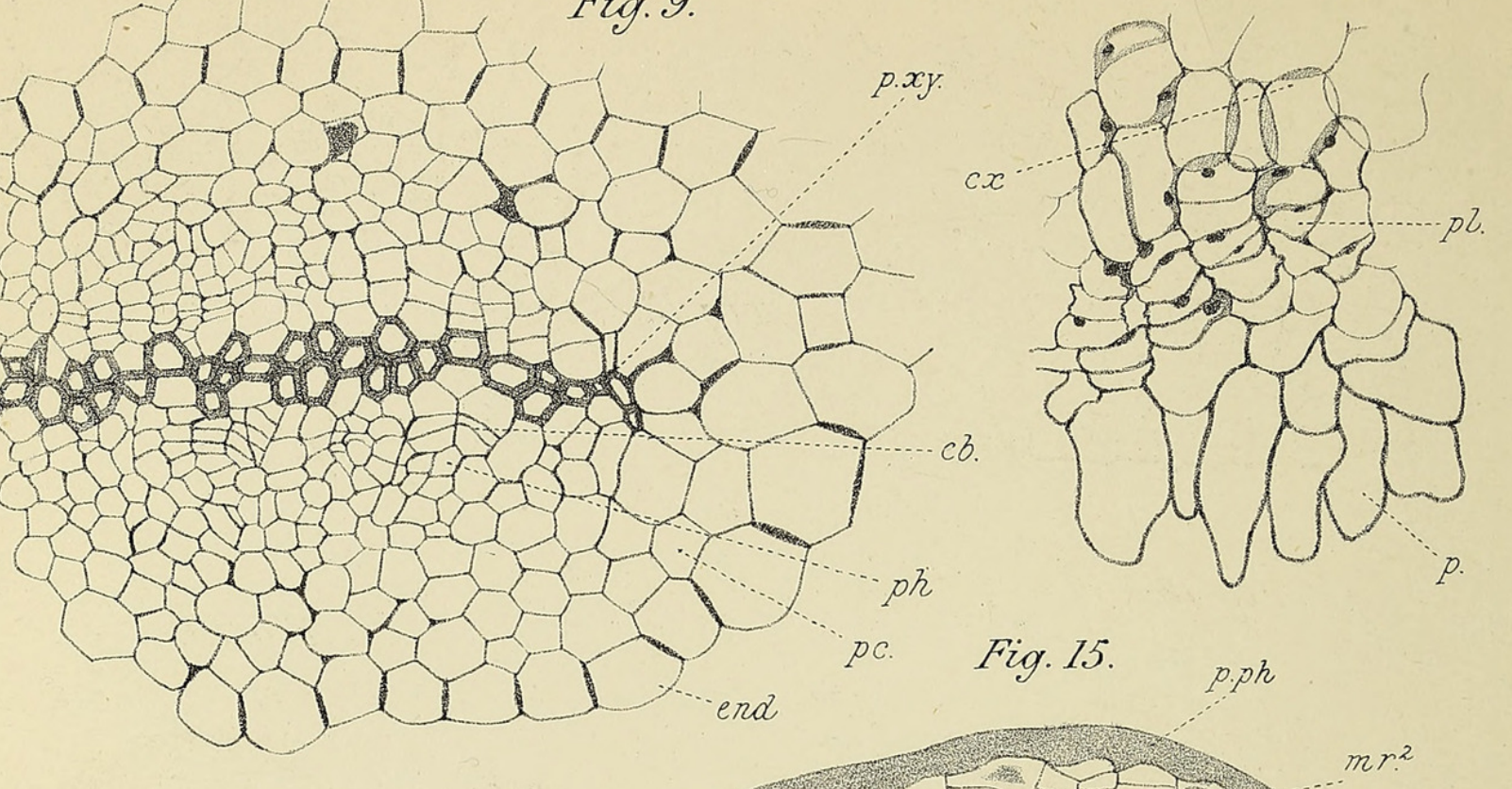

Fig. 13.

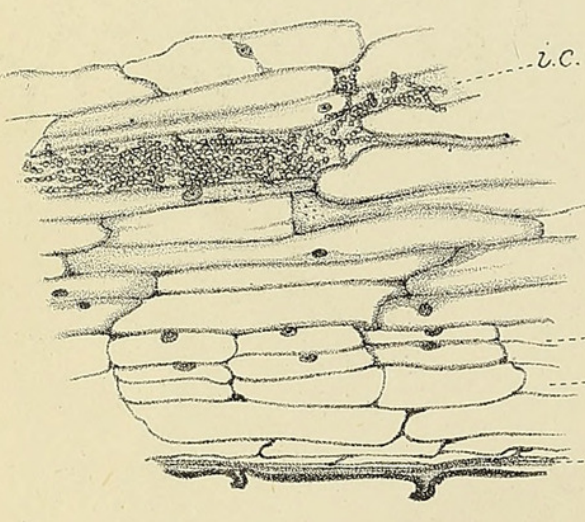

Fig. 14.
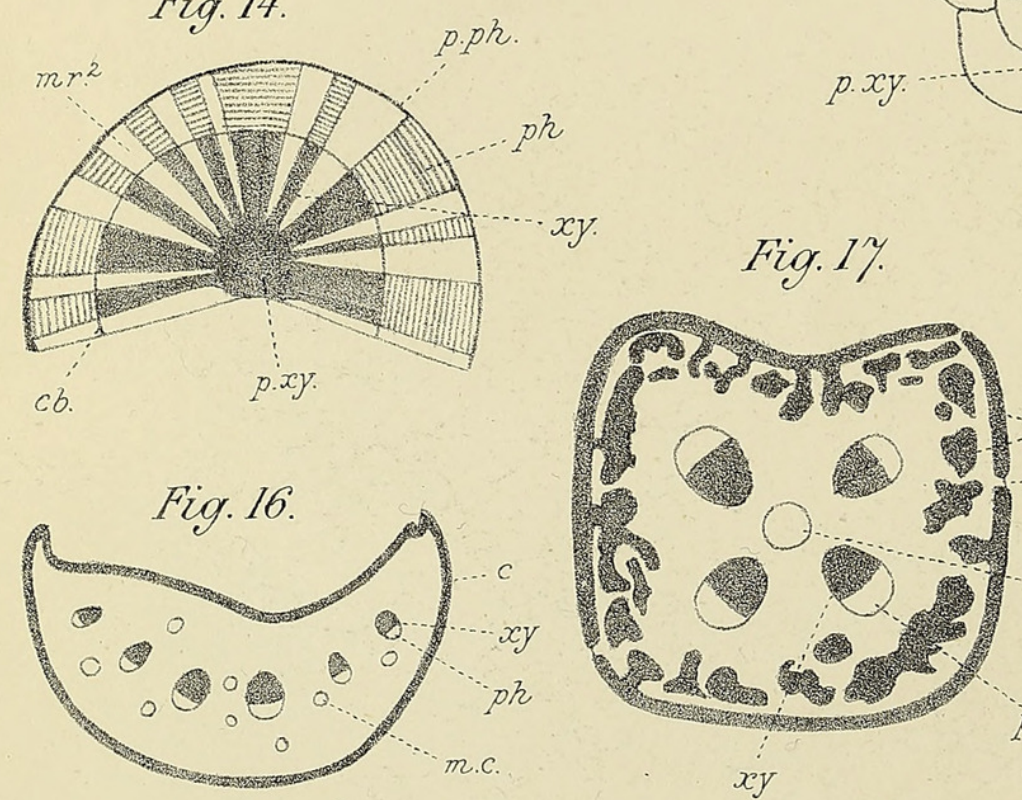

Fig. $15 . \quad$ p.ph

Fig. 15. p.ph
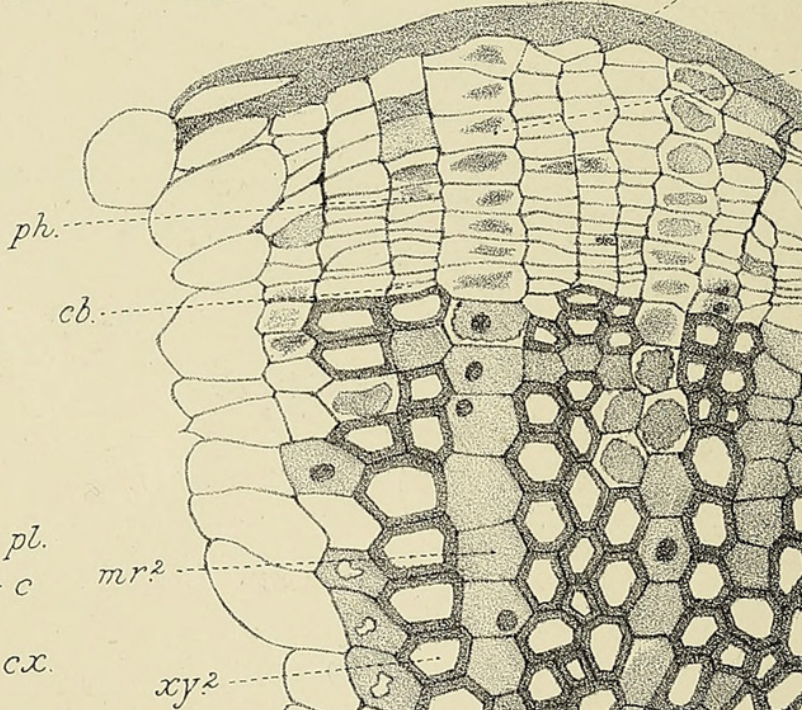

b.
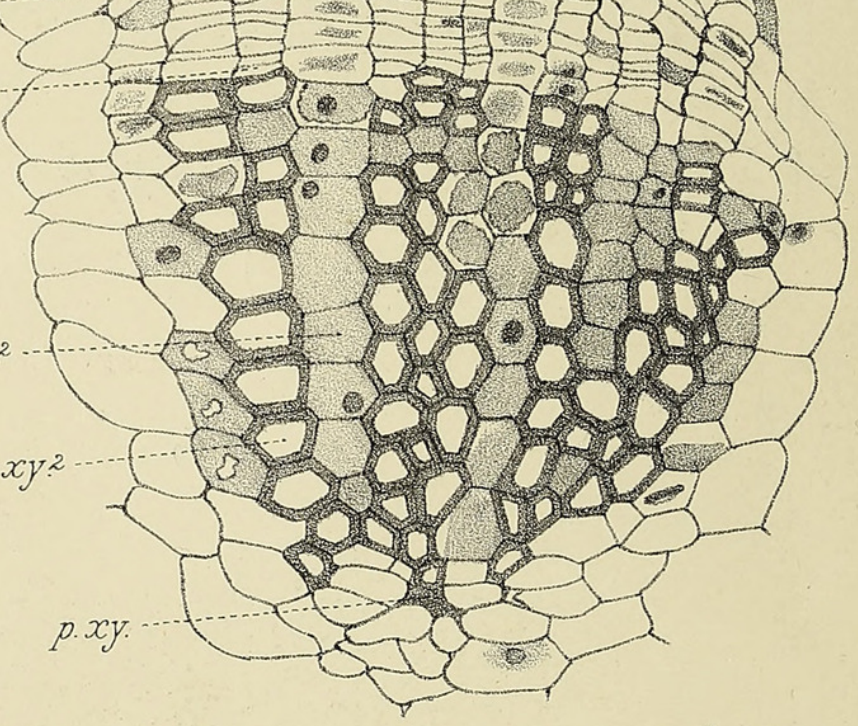

p.ph.

Fig. 20.

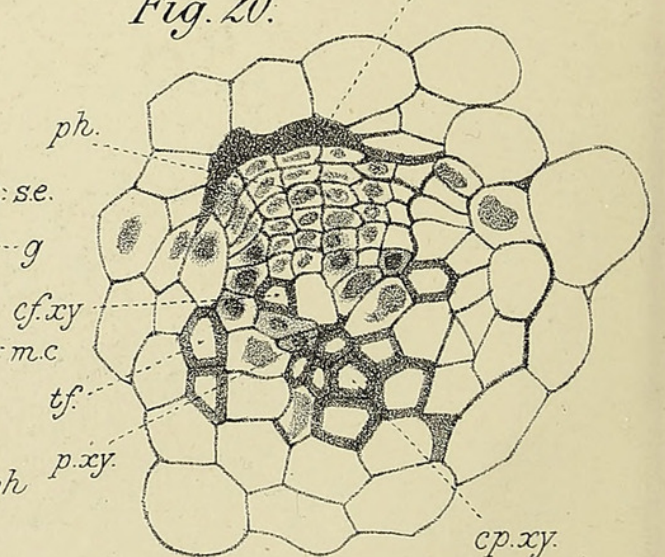

H.H.W.Pearson del.

PEARSON. - BOWENIA. 
VoL. XII, PI.XXVIII.
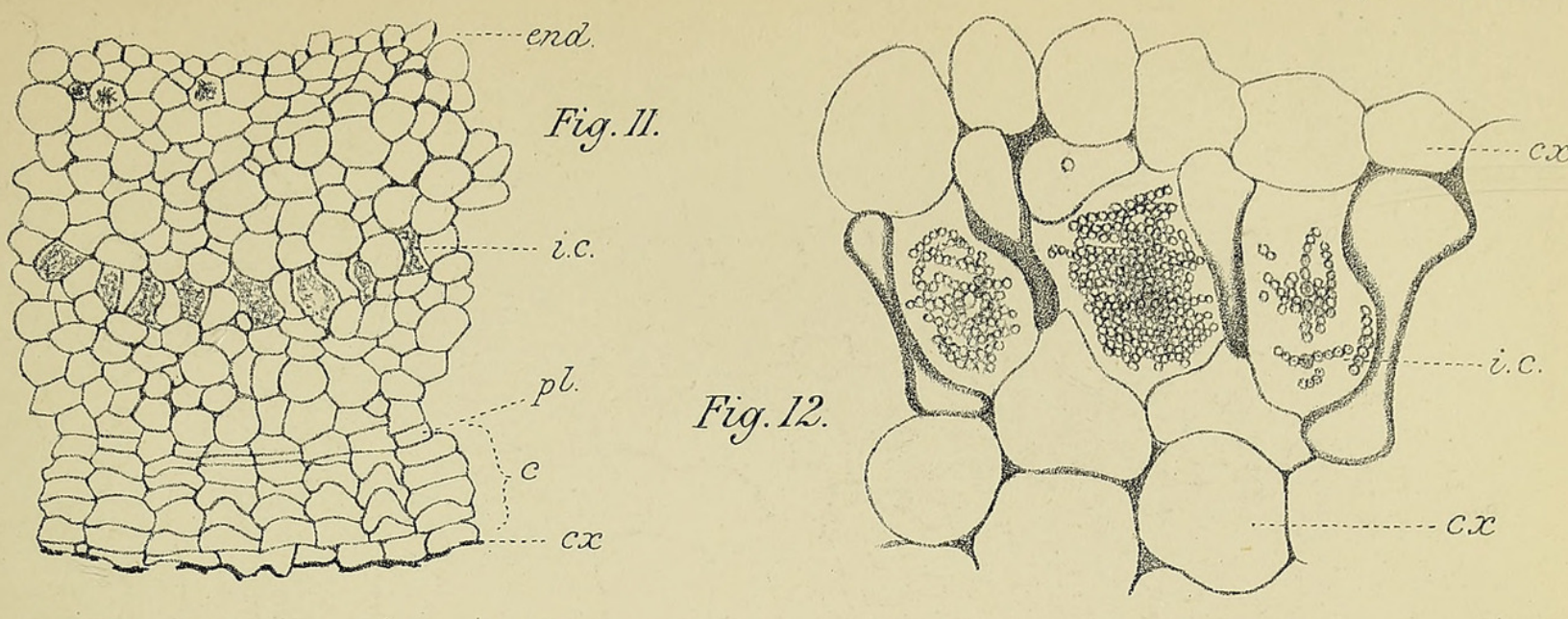

Fig. 18.
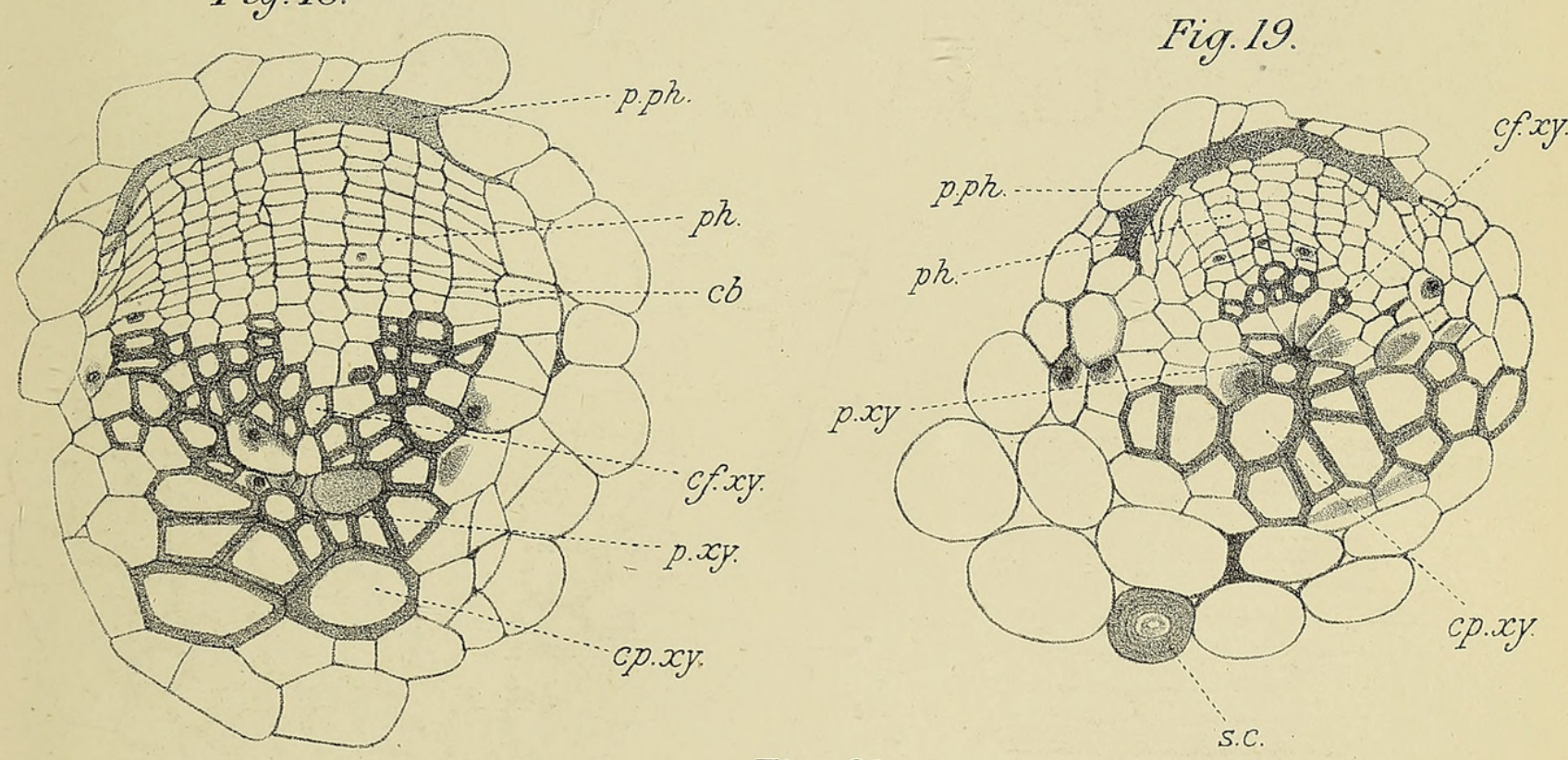

Fig. 21.

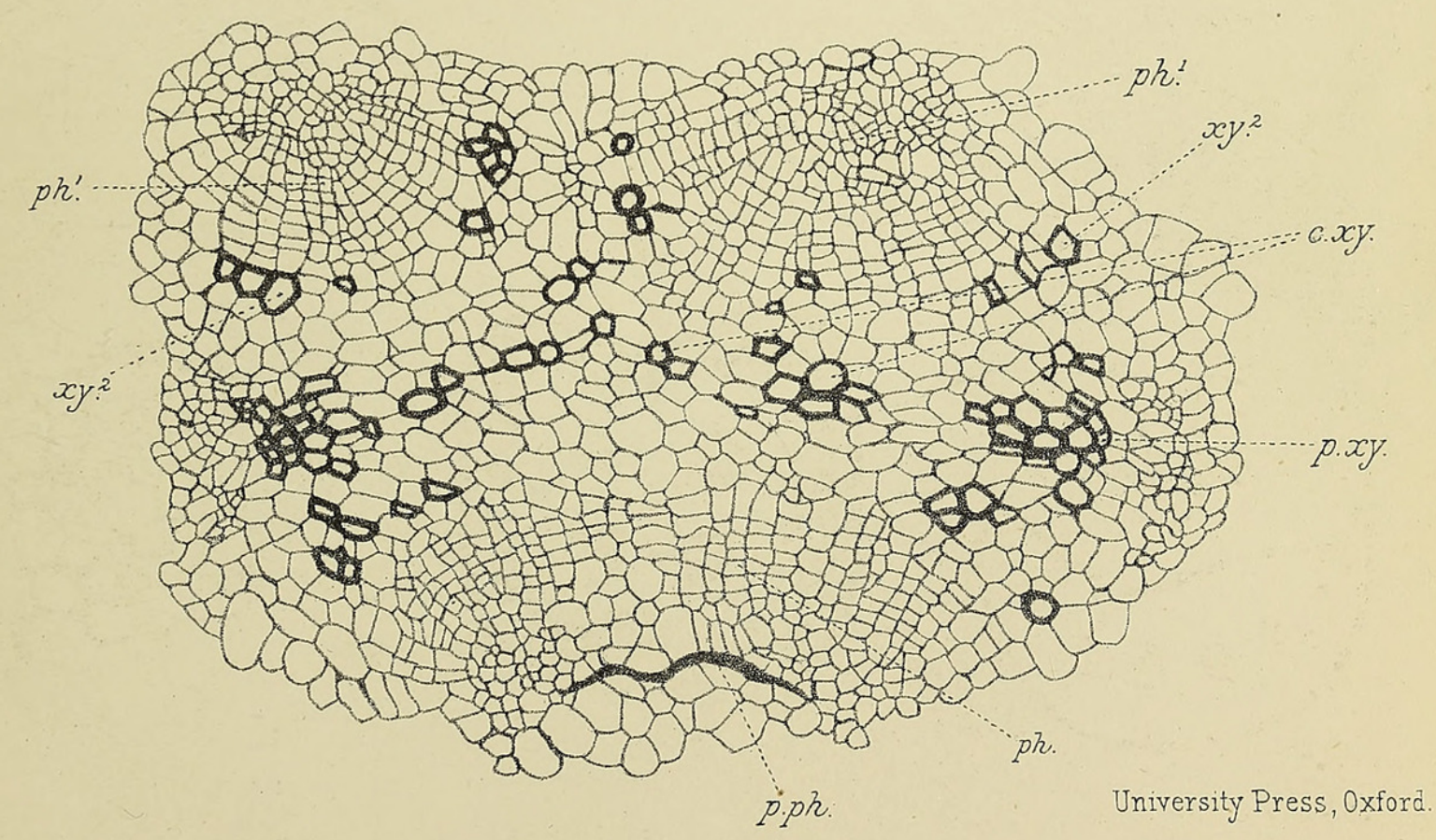




\section{$2 \mathrm{BHL}$ Biodiversity Heritage Library}

Pearson, H H W . 1898. "Anatomy of the seedling of Bowenia spectabilis, Hook. f." Annals of botany 12, 475-490.

https://doi.org/10.1093/oxfordjournals.aob.a088704.

View This Item Online: https://www.biodiversitylibrary.org/item/233102

DOI: https://doi.org/10.1093/oxfordjournals.aob.a088704

Permalink: https://www.biodiversitylibrary.org/partpdf/318516

\section{Holding Institution}

Smithsonian Libraries

\section{Sponsored by}

Biodiversity Heritage Library

\section{Copyright \& Reuse}

Copyright Status: Not in copyright. The BHL knows of no copyright restrictions on this item.

This document was created from content at the Biodiversity Heritage Library, the world's largest open access digital library for biodiversity literature and archives. Visit BHL at https://www.biodiversitylibrary.org. 